\title{
An Empirical Analysis of the Impact of Energy Consumption on the Financial Development of the Emerging Economies: A Moderating Role of Oil Prices
}

\author{
Faisal Mahmood ${ }^{1} \&$ Maria Saleem $^{1}$ \\ ${ }^{1}$ Lahore Business School, the University of Lahore, Lahore, Pakistan \\ Correspondence: Faisal Mahmood, Lahore Business School, the University of Lahore, 1-KM defense road \\ Lahore, Punjab, Pakistan. Tel: 920-301-712-2707. E-mail: faisalch62@yahoo.com
}

Received: June 21, 2016

doi:10.5539/ijef.v8n9p26
Accepted: July 14, 2016

Online Published: August 25, 2016

\begin{abstract}
This research empirically analyzes the relationship between energy consumption and financial development by making use of secondary data for 22 emerging economies over the period of 1999-2012. Moreover, this paper also spotlights the moderating role of oil prices. Furthermore, financial development is measured by utilizing of various proxies relevant to banking sector and stock market as well. Hence, the findings of the research reveals that oil prices negatively moderates the relationship between energy consumption and financial development. Moreover, results highlight that measures used to calculate financial development are also of key concern to explore the relationship between energy consumption and financial development.
\end{abstract}

Keywords: energy consumptions, oil prices, emerging economies, financial development

\section{Introduction}

In today's globalized world, every country is striving for resources to make progress. However, these resources are limited in their existence. For instance, oil is among one of the most desirable resource in this world. Thus, it plays central role in the development of this world. Moreover, several countries have sufficient oil reserves. Therefore, they export oil to those countries with low or no oil reserves. For instance, China is among one of the leading oil importer in this world. Whereas, Middle East countries are rich in the oil reserves and their economic development mainly depends on the oil exports.

Thus, it is significant to keep track the performance of both oil exporting and importing countries. It is also essential to uncover the impact of fluctuations in oil prices and its respective impact on the economic growth. Hence, the existing body of literature has documented the relationship between energy consumption and financial development of economies in great deal for instance (Çoban \& Topcu, 2013; Komal \& Abbas, 2015; Naser, 2015; Sadorsky, 2011; Wu \& Broadstock, 2015). However, no final consensus have been established so for.

The objective of this research is to evaluate an essential research question that is of key concern for both academic researchers and financial practioners as well. Does energy consumption derives financial development? Moreover, this research also focuses on another question that is also of key importance: Does oil prices moderates the relationship between energy consumption and financial development? Therefore, the purpose of this study is to explore the impact of energy consumption on financial development of 22 emerging economies by considering the oil prices as moderator variable.

This study significantly contributes to the existing body of literature by highlighting oil prices as moderator variable. This study assumes that the relationship between energy consumption and financial development is moderated by oil prices. Hence, it is essential to explore this relationship to suggest financial policy makers a vital piece of information to devise such policies that stimulate economic growth and to deal with fluctuations in oil prices.

Accordingly, this research makes use of energy consumption, energy imports, alternative energy and trade as explanatory variables. Furthermore, this research is also contributing to the existing stream of literature by measuring financial development by making use of both stock market and banking sector variables. 


\section{Literature Review}

Although, in this era of globalization this world is making headways in attractive manners. However, there exists various issues as well. For instance, energy resources are limited. Hence, economies are striving to make efficient use of energy resources. Thus, since last decade existing stream of literature have documented various studies that have explored the relationship between energy consumption and financial development (Ahmed, Riaz, Khan, \& Bibi, 2015; Hasnaoui, 2014; Naser, 2015; Wu \& Broadstock, 2015).

However, the objective of this research is to enlighten the impact of energy consumption on financial development by highlighting the moderating role of oil prices for emerging economies.

Asafu-Adjaye (2000) documents the empirical relationship between economic growth, energy consumption and oil prices by making use of co-integration and reveals that there exist relationship between energy and income. However, this relationship remains neutral in the short run in the context of India and Indonesia. Moreover, this study also documents that, there exists diversity in the results due to different methods and proxies that have been used to measure both energy consumption and economic growth. Hence, the variables of the study consists of commercial energy, real income and prices. Furthermore, the existing studies have also made use of similar methods to empirically investigate the relationship that is particularly called common method biased. For instance ordinary least square. However, the recent stream of literature also put question on the stationary of data on economic growth. Hence, results may be ambiguous. Thus, this study has investigated Thailand, Indonesia, India and Philippines. Moreover, this research used Augmented Dickey Fuller test for Stationary. Furthermore, Johnson's maximum likelihood and Temporal Granger Causality test is also employed. Thus, findings uncover that there exists causal relationship between the variables under study and also negated the neutrality hypotheses.

Al-mulali and Sab (2012) explores the financial development of nineteen countries by analyzing the impact of energy consumption and CO2 emissions over the period of 1998-2008 and finds that, although energy consumption has positive impact on the financial development of these countries. But there is also increase in the pollution due to increase in $\mathrm{CO} 2$ emissions. Hence, these countries should focus on the reduction in the $\mathrm{CO} 2$ emissions.

There exists crucial energy problems in Pakistan that is influencing its economic growth as well. Moreover, high dependence on imported energy resources is also causing problems. Thus, Pakistan should focuses on alternative energy resources as well. Furthermore, non-traditional renewable energy resources should also be considered in-order to reduce international prices impact. Solar power, biomass and solid wastage should also be considered (Ahmed et al., 2015). Çoban and Topcu (2013) finds positive relationship between financial development and energy consumptions. Moreover, this relationship exists irrespective of either the financial development is measured by making use of banking or stock market for the European union over the period of 1990-2011. Furthermore, this research also reveals that financial development influences energy consumption by depending upon the measurement of financial development for new European Union members.

Komal and Abbas (2015) explores the relationship between energy consumption, economic growth and financial development over the period of 1972-2012 in the contexts of Pakistan by making use of GMM processes. Thus, this study reveals the statistically significant positive relationship between economic growth and energy consumption. However, there exists negative relationship between energy consumption and prices.

Huang, Hwang, and Yang (2008) investigate the impact of energy consumption on economic growth by dividing datasets into four groups. Hence, in lower income group, they did not find any relationship between energy consumption and economic growth. Moreover, economic growth derives energy consumption in lower middle income group. However, economic growth has negative impact on energy consumption in high income group. Hence, one justification for this negative relationship is that reduced emission of $\mathrm{CO} 2$ in developed economies. Furthermore, there is no impact of energy consumption on economic growth. The relationship between financial growth and energy consumption also depends upon the methods that have been used to measure financial development. There exists statistically significant positive impact of financial development on energy consumption by measuring financial development by stock market index. However, there is negative relationship between stock market activity and energy consumption (Hasnaoui, 2014).

Shahbaz, Hye, Tiwari, and Leitão (2013) documented that an increase in $\mathrm{CO} 2$ is derived by increased economic growth and energy consumptions. However, financial development and traded openness reduced it. Moreover, this research also spotlights new ways to save environment by making use of energy efficient technologies. Furthermore, healthy environmental conditions are also supported by an increase in financial development and trade openness. Sadorsky (2010) probed that financial development seems to be a key factor to derive economic growth in emerging economies. Hence, the finding of the study suggests the statistically significant positive 
relationship between energy consumption and financial development.

Lee and Chang (2005) enlightens the relationship between energy consumption and gross domestic product over the period of 1954-2003 for Taiwan. Thus, results of the study spotlights that energy consumption is the lifeblood for economic growth. Moreover, conservative energy policies can damage economic growth. Odhiambo (2010) comparatively analyzed the liaison between energy consumption and economic growth in the context of South Africa, Congo and Kenya and suggests variations in this relationship across these countries. For instance, energy consumption derives economic growth in both South Africa and Kenya. While there exist significant impact of economic growth on energy consumption in the case of Congo. Conservative energy policies can decrease the economic growth for emerging economies. Furthermore, there exist long run relationship between energy consumption and economic growth (Naser, 2015). Mehrara (2007) put lights on the relationship between energy consumption and economic growth for oil exporting economies.

There exits positive impact of economic growth on energy consumption. There exists strong relationship between energy consumption and economic growth. Moreover, both energy consumption and GDP per capita is affected due to energy crises. Furthermore, this research uncovered the bidirectional relationship regarding developed countries and unidirectional relationship in the context of developing countries for both energy consumption and GDP per capita (Lee \& Chang, 2007).

Thus, it can be inferred from the existing body of literature that: there exist both unidirectional and bidirectional relationship among financial development and energy consumption. Although, the existing body of literature have revealed this relationship in a great dealt. However, there are several aspect as well that must also be considered to solve this dilemma. For instance, this research makes use of oil prices as a moderator to investigate the relationship between financial development and energy consumption for emerging economies. Hence, it is useful to uncover the moderator role of oil prices in the context of emerging economies.

\section{Research Design and Methodology}

This section is further consists of two sub-sections. Sub-section 3.1 comprises of the data and variables of the study. Furthermore, sub-section 3.2 highlights research hypotheses, research methods and empirical models.

\subsection{The Data}

The data used in this research are secondary data collected from World Bank and DataStream databases over the period of 1999-2012 for 22 emerging economies. Hence, Table 1 put lights on the variables of the study. Table 1 put lights on the variables of the study. This research makes use of financial development as dependent variable of the study. Hence, financial development is measured by utilizing both banking and stock market variables. Banking sector variables considered in this study includes bank concentration ratio, bank deposit to GDP ratio, bank return on asset, bank return on equity and Z-score. While stock market indicators comprises of stock market return, stock market capitalization, stock market turnover ratio and stock market volatility. Moreover, energy consumption, energy imports, alternative energy and trade are the explanatory variables. Furthermore, oil prices is incorporated as moderator variable.

Table 1. Variables measurements

\begin{tabular}{ll}
\hline \multicolumn{1}{c}{ Variable } & \multicolumn{1}{c}{ Deasurements } \\
\hline Financial Development & Banking and Stock market variables \\
Banking variables & Bank concentration ratio \\
& Bank deposit to GDP ratio \\
& Bank return on asset \\
& Bank return on equity \\
& Bank z-score \\
& Stock market return \\
Stock market variables & Stock market capitalization \\
& Stock market turnover ratio \\
& Stock market volatility \\
\hline & $\quad$ Independent variables \\
\hline Energy consumption & Energy use (kg of oil equivalent per capita) \\
Energy imports & Energy imports, net (\% of energy use) \\
Alternative energy & Alternative and nuclear energy (\% of total energy use) \\
\hline
\end{tabular}




\begin{tabular}{lc}
\hline Trade & Trade (\% of GDP) \\
\hline Oil Prices & Moderator variable \\
\hline
\end{tabular}

Note. Table 1 highlights the variables considered in this research. Financial development is dependent variable and is measured by making use of both banking sector and stock market variables. Furthermore, energy consumption, energy imports, alternative energy and trade are the explanatory variables. Moreover, oil prices is included as moderator variable.

Data source: World Bank and DataStream

\subsection{Hypotheses of the Study}

This research focuses on the four research hypotheses. H1: "Energy consumption positively influences the financial development of emerging economies." H2: "Energy imports have positive impact on the financial development of emerging economies." H3: "There exists negative relationship between Alternative energy and the financial development of emerging economies." H4: "Oil prices moderate the relationship between energy consumption and financial development."

\subsubsection{Empirical Models}

This research make use of following empirical models in-order to investigate the relationship between independent and dependent variables.

$$
\begin{gathered}
F D i t=\beta 0+\beta 1 E C i t+\beta 2 \text { EIit }+\beta 3 A E i t+\beta 4 \text { TR it }+\varepsilon i t \\
F D i t=\beta 0+\beta 1 E C i t+\beta 2 \text { EIit }+\beta 3 A E i t+\beta 4 \text { TR it }+\beta 5 O P i t+\varepsilon i t
\end{gathered}
$$

Where, FD stands for financial development, EC signify energy consumption, AE enlightens alternative energy and TR represents trade. Moreover, $\beta 1-\beta 4$ are the coefficients of the explanatory variable respectively. $\varepsilon i t$ is the error term that is independently identically distributed random variables as well. Whereas in model 2, OP put lights on the oil prices that is included as moderator variables in the study. Financial development is further measured by making use of various proxies as explained in the Table 1.

\subsubsection{Methods and Procedures}

This research makes use of panel data procedures because the data used in this study panel data for 22 emerging economies over the period of 2000-2012. To test the impact of independent variables on dependent ordinary least square regressions have been used. Moreover, to overcome the panel data drawbacks fixed effect model is used by depending upon the Hausman test results.

\section{Empirical Results}

To empirically analyze the research question. First of all, descriptive statistics have been measured. Moreover, correlation among explanatory variables have been tested. Accordingly, the results show that the data is free of multicollinearity problem.

\begin{tabular}{|c|c|c|c|c|c|}
\hline & $\mathrm{EC}$ & EI & ALE & Trade & Oil Prices \\
\hline EC & 1 & & & & \\
\hline EI & -0.77 & 1 & & & \\
\hline ALE & 0.25 & -0.30 & 1 & & \\
\hline Trade & 0.26 & -0.05 & 0.23 & 1 & \\
\hline Oil prices & 0.008 & -0.02 & 0.04 & 0.10 & 1 \\
\hline
\end{tabular}

Table 2. Correlation

Note. Table 2 incorporates the correlation results among explanatory variables. Where EC stands for energy consumption. EI represents energy imports. ALE signifies alternative energy. Moreover, other variables includes trade and oil prices.

Data Source: World Bank and Data Stream. 
Table 3. Summary statistics

\begin{tabular}{lccccc}
\hline \multicolumn{1}{c}{ Variables } & Obs. & Mean & St. Dev. & Min. & Max. \\
\hline Bank concentration ratio & 282 & 64.63 & 24.40 & 7.24 & 100 \\
Bank deposit to GDP ratio & 281 & 50.53 & 25.06 & 12.44 & 126.25 \\
Bank return on asset & 292 & 1.16 & 2.73 & -28.07 & 20.51 \\
Bank return on equity & 292 & 11.68 & 23.46 & -275.58 & 178.94 \\
Bank z-score & 292 & 17.69 & 11.94 & -3.72 & 62.91 \\
Stock market return & 280 & 56.31 & 43.80 & 9.88 & 253.91 \\
Stock market capitalization & 279 & 16.06 & 33.30 & -38.78 & 169.91 \\
Stock market turnover ratio & 279 & 56.88 & 48.27 & 2.47 & 313.18 \\
Stock market volatility & 277 & 26.10 & 10.68 & 7.77 & 89.51 \\
Energy consumption & 294 & 2882.14 & 4169.17 & 430.77 & 22762.08 \\
Energy imports & 294 & -38.74 & 125.52 & -560.12 & 73.86 \\
Alternative energy & 294 & 10.85 & 20.59 & 0 & 99.95 \\
Trade & 292 & 76.12 & 42.36 & 20.89 & 220.40 \\
Oil prices & 294 & 51.27 & 28.89 & 11.74 & 99.03 \\
\hline
\end{tabular}

Note. Table 3 put lights on the descriptive statistics of all the variables considered in this study. Obs. Stands for number of observation. Mean is the central tendency of the data. St.Dev. represents standard deviation. Min is the minimum value and Max is the maximum value in the dataset for respective variables.

Data Source: World Bank and Data Stream.

Table 4. Impact of independent variables on dependent variables by making use OLS

\begin{tabular}{lccccccccc}
\hline & M.1 & M.2 & M.3 & M.4 & M.5 & M.6 & M.7 & M.8 & M.9 \\
\hline Constant & BCR & BDGR & BROA & BROE & BZS & SMR & SMC & SMT & SMV \\
& $52.89^{*}$ & $23.54^{*}$ & $0.702^{*}$ & $5.48^{* * *}$ & $15.55^{*}$ & $29.58^{*}$ & $30.64^{*}$ & $64.36^{*}$ & $34.09^{*}$ \\
Energy & $(3.54)$ & $(2.93)$ & $(0.42)$ & $(3.64)$ & $(1.83)$ & $(5.17)$ & $(6.04)$ & $(7.25)$ & $(1.572)$ \\
consumption & 0.0001 & -0.0004 & 0.00005 & 0.0003 & $0.0004^{* * *}$ & -.0008 & $-0.002^{*}$ & $.003^{*}$ & $.001^{*}$ \\
Energy imports & $(0.0005)$ & $(0.00)$ & $(0.000)$ & $(0.0006)$ & $(0.0002)$ & $(.001)$ & $(0.001)$ & $(.001)$ & $(.0003)$ \\
& -0.018 & $0.020^{* * *}$ & -0.001 & -0.0032 & -.003 & -.045 & $-0.143^{*}$ & $.167^{*}$ & $.023^{*}$ \\
Alternative & $(0.018)$ & $(0.015)$ & $(0.002)$ & $(0.019)$ & $(.009)$ & $(.027)$ & $(0.03)$ & $(.037)$ & $(.008)$ \\
energy & $-0.307^{*}$ & $-0.421^{*}$ & 0.003 & 0.0119 & .038 & .001 & $-1.11^{*}$ & .083 & -.012 \\
Trade & $(0.074)$ & $(0.08)$ & $(0.008)$ & $(0.077)$ & $(.038)$ & $(.121)$ & $(0.18)$ & $(.218)$ & $(.038)$ \\
& $0.212^{*}$ & $0.385^{*}$ & 0.002 & 0.0218 & .003 & -.061 & $0.32^{*}$ & $-.168^{*}$ & $-.066^{*}$ \\
Oil prices & $(0.034)$ & $(0.02)$ & $(0.004)$ & $(0.036)$ & $(.018)$ & $(.051)$ & $(0.06)$ & $(.072)$ & $(.015)$ \\
& -0.04 & $0.060^{* * *}$ & 0.00003 & $0.0658^{* * *}$ & .003 & $-.149 *$ & $0.23^{*}$ & .0009 & $-.088^{*}$ \\
$\mathrm{R}^{2}$ & $(0.047)$ & $(0.03)$ & $(0.005)$ & $(0.048)$ & $(.024)$ & $(.069)$ & $(0.08)$ & $(.098)$ & $(.021)$ \\
Adjusted $-\mathrm{R}^{2}$ & 0.1610 & 0.4368 & 0.027 & 0.015 & 0.038 & 0.037 & 0.2189 & 0.074 & 0.1391 \\
Prob.> F & 0.1457 & 0.4266 & 0.010 & 0.002 & 0.021 & 0.019 & 0.2047 & 0.057 & 0.1232 \\
\hline
\end{tabular}

Note. Table 4 explains the impact of explanatory variables on the dependent by making use of OLS regressions. M.1 to M.8 stands for the model 1 to model 8 as this paper makes use of more than one proxies to measures dependent variable. BCR is the bank concentration ratio, BDRG is the bank deposit to GDP ratio, BROA stands for bank return on asset, BROE represent bank return on equity, BZS put lights on the Bank Z-score, SMR spotlights stock market returns. SMC is the stock market capitalization, SMT signify stock market turnover and SMV explains stock market volatility.

Data source: Self calculated on World bank and Data Stream data.

Table 4 represents the OLS regression results. The dependent variable financial development is measured by making use of nine proxies. In model 1, bank concentration ratio is dependent variable. Thus, alternative energy and trade are statistically and economically significant at $1 \%$ significance level. With one unit increase in alternative energy, the financial development decreases by 0.30 units by keeping all other things ceterus paribus.

Moreover, with one unit increase in trade, the financial development increases by 0.21 units by keeping all other things constant. Bank deposit and GDP ratio is included as respondent variable in model 2. Energy imports, alternative energy, trade and oil prices have statistically and economically significant impact on dependent variable at $10 \%, 1 \%, 1 \%$ and $10 \%$ respectively. However, in model 3 , all the variables remain statistically 
insignificant. In model 4, bank return on equity is dependent variable. Oil prices have statistically significant impact on financial development at $10 \%$ significance level. Whereas, in model 5 , energy consumption has statistically and economically significant impact on the financial development that is measured by making use of bank $\mathrm{z}$-score at $10 \%$ significance level. If there is one unit increase in energy consumption, financial development increases by 0.0004 units. Model 6, represents the results by considering stock market return as measure of financial development. Oil prices have statistically and economically significant negative impact on the financial development. With one unit increase in oil prices, financial development decreases by 0.149 units by keeping all other things constant.

Moreover, model 7 comprises of the results by using stock market capitalization. Alternative energy and trade is statistically and economically significant at $1 \%$ significance level. However, rest of the variables are statistically significant but economically insignificant. Furthermore, energy consumption and energy import has statistically and economically significant positive impact on financial development at $1 \%$ significance level in model 8 . Energy consumption and energy import has statistically and economically significant positive impact on the financial development at $1 \%$ significance level. However, oil prices have also statistically and economically significant negative impact on financial development at $1 \%$ significance level in model 9.

Table 5. The moderating role of oil prices

\begin{tabular}{|c|c|c|c|c|c|c|c|c|c|}
\hline & M.1 & M.2 & M.3 & M.4 & M.5 & M.6 & M.7 & M.8 & M.9 \\
\hline & $B C R$ & BDGR & BROA & BROE & $B Z S$ & SMR & SMC & SMT & $S M V$ \\
\hline & R.E & F.E & R.E & R.E & F.E & R.E & F.E & R.E & F.E \\
\hline Constant & $\begin{array}{c}53.83 * \\
(6.56)\end{array}$ & $\begin{array}{c}37.51 * \\
(4.03)\end{array}$ & $\begin{array}{l}0.61 * \\
(0.46)\end{array}$ & $\begin{array}{c}4.21 \\
(4.05)\end{array}$ & $\begin{array}{l}-2.82 \\
(4.11)\end{array}$ & $\begin{array}{c}28.36^{*} \\
(6.21)\end{array}$ & $\begin{array}{c}0.59 \\
(11.09)\end{array}$ & $\begin{array}{l}73.07 * \\
(14.91)\end{array}$ & $\begin{array}{c}37.03 * \\
(6.94)\end{array}$ \\
\hline $\begin{array}{l}\text { Energy } \\
\text { consumption }\end{array}$ & $\begin{array}{l}-0.0009 \\
(0.0008)\end{array}$ & $\begin{array}{c}0.0005 \\
(0.0009)\end{array}$ & $\begin{array}{c}0.00008 \\
(0.000)\end{array}$ & $\begin{array}{c}0.0006 \\
(0.0007)\end{array}$ & $\begin{array}{l}0.0011 * \\
(0.0006)\end{array}$ & $\begin{array}{c}-0.0002 \\
(.002)\end{array}$ & $\begin{array}{c}0.014^{*} \\
(.002)\end{array}$ & $\begin{array}{l}.003 * * \\
(.002)\end{array}$ & $\begin{array}{c}-.004^{* *} \\
(.002)\end{array}$ \\
\hline $\begin{array}{l}\text { Energy } \\
\text { imports }\end{array}$ & $\begin{array}{c}-0.048 * * \\
(0.027)\end{array}$ & $\begin{array}{c}0.028^{* *} \\
(0.028)\end{array}$ & $\begin{array}{l}-0.001 \\
(0.002)\end{array}$ & $\begin{array}{l}-0.005 \\
(0.019)\end{array}$ & $\begin{array}{l}-.002 \\
(.001)\end{array}$ & $\begin{array}{c}-0.046^{* * *} * \\
(.02)\end{array}$ & $\begin{array}{c}-0.306^{*} \\
(.07)\end{array}$ & $\begin{array}{l}0.17 * \\
(.07)\end{array}$ & $\begin{array}{c}-0.033 \\
(.0 .035)\end{array}$ \\
\hline $\begin{array}{l}\text { Alternative } \\
\text { energy }\end{array}$ & $\begin{array}{l}-0.17 \\
(0.22)\end{array}$ & $\begin{array}{l}1.074^{*} \\
(0.35)\end{array}$ & $\begin{array}{c}0.003 \\
(0.008)\end{array}$ & $\begin{array}{c}0.011 \\
(0.077)\end{array}$ & $\begin{array}{l}1.23 * \\
(.033)\end{array}$ & $\begin{array}{l}-0.012 \\
(0.12)\end{array}$ & $\begin{array}{c}-2.10 * * \\
(0.98)\end{array}$ & $\begin{array}{c}0.22 \\
(0.49)\end{array}$ & $\begin{array}{l}-0.029 \\
(0.48)\end{array}$ \\
\hline Trade & $\begin{array}{l}0.23^{*} \\
(0.05)\end{array}$ & $\begin{array}{l}-0.020 \\
(0.03)\end{array}$ & $\begin{array}{c}0.002 \\
(0.004)\end{array}$ & $\begin{array}{c}0.024 \\
(0.036)\end{array}$ & $\begin{array}{c}.003 \\
(.018)\end{array}$ & $\begin{array}{l}-0.061 \\
(.051)\end{array}$ & $\begin{array}{l}0.304 * \\
(.0106)\end{array}$ & $\begin{array}{l}-0.31 * \\
(0.13)\end{array}$ & $\begin{array}{l}-0.042 \\
(0.052)\end{array}$ \\
\hline Oil prices & $\begin{array}{c}-0.03 * * * \\
(0.02)\end{array}$ & $\begin{array}{c}0.076^{*} \\
(0.01)\end{array}$ & $\begin{array}{c}0.001 \\
(0.006)\end{array}$ & $\begin{array}{c}0.090 * * * \\
(0.059)\end{array}$ & $\begin{array}{l}-0.012 \\
(0.016)\end{array}$ & $\begin{array}{c}-0.129 * * * \\
(0.09)\end{array}$ & $\begin{array}{c}0.322^{*} \\
(.05)\end{array}$ & $\begin{array}{l}-0.05 \\
(0.07)\end{array}$ & $\begin{array}{c}-0.049 * * \\
(0.025)\end{array}$ \\
\hline Moderator & $\begin{array}{c}-0.0001 * * \\
(0.0000)\end{array}$ & $\begin{array}{l}-0.0003 \\
(0.0000)\end{array}$ & $\begin{array}{c}-0.00006 \\
(0.0001)\end{array}$ & $\begin{array}{l}-0.0008 \\
(0.001)\end{array}$ & $\begin{array}{l}-0.0001 \\
(0.0008)\end{array}$ & $\begin{array}{l}-0.00009 \\
(0.0002)\end{array}$ & $\begin{array}{c}-0.00006^{*} \\
(0.00001)\end{array}$ & $\begin{array}{l}-0.00002 \\
(0.00002)\end{array}$ & $\begin{array}{c}-0.0001^{* * *} * \\
(0.00008)\end{array}$ \\
\hline $\mathrm{R}^{2}$ within & 0.08 & 0.16 & 0.0005 & 0.009 & 0.03 & 0.01 & 0.31 & 0.045 & 0.1369 \\
\hline Prob. $>$ chi $^{2}$ & 0.000 & 0.000 & 0.22 & 0.55 & 0.045 & 0.09 & 0.000 & 0.04 & 0.000 \\
\hline
\end{tabular}

Note. Table 5 explains the impact of explanatory variables on the dependent by making use of fixed and random effect model. M.1 to M.8 stands for the model 1 to model 8 as this paper makes use of more than one proxies to measures dependent variable. BCR is the bank concentration ratio, BDRG is the bank deposit to GDP ratio, BROA stands for bank return on asset, BROE represent bank return on equity, BZS put lights on the Bank Z-score, SMR spotlights stock market returns. SMC is the stock market capitalization, SMT signify stock market turnover and SMV explains stock market volatility. Moreover, F.E represents fixed effect model and R.E signifies random effect model.

Data source: Self calculated on World bank and DataStream data

Table 5 put lights on the impact of independent variables on dependent by making use of panel data procedures. For instance, Hausman test is used to differentiate between fixed and random effect model. There is sufficient change on the coefficients of all models by making use of fixed and random effect model. Moreover, impact of moderator variable is also highlighted in Table 5. In model 1, the moderator variables is negatively influencing the financial development measured by making use of bank concentration ratio. Moreover, this result is also statistically significant at $5 \%$ significance level. Thus, do not reject $\mathrm{H} 1$, as results suggest that moderator variable negatively influences the financial development. In model 2 , there is also negative moderating impact but it remains statistically insignificant. There is also statistically significant negative moderating role of oil prices on financial development of emerging economies in model 3, 4, 5 and 6. However, there exists statistically and economically negative impact of moderator variable on financial development that is measured by utilizing stock market capitalization. Thus, do not reject H1. Furthermore, it remains statistically insignificant in model 8 as 
well. Whereas, there is statistically and economically significant negative impact of the moderator in model 9 . Thus, a unit increase in moderating role of oil prices, the financial development decreases by 0.0001 units by keeping all other things constant.

\section{Conclusions}

This empirical study investigates the relationship between energy consumption and financial development in the context of 22 emerging economies over the period of 1999-2012. Moreover, moderating role of oil prices is also explored in this research. Furthermore, financial development is measured by making use of various proxies relevant to banking sector and stock market as well.

Thus, overall this research investigates nine models. Energy consumption has diverse impact on the financial development in the context of different models. It has statistically and economically significant impact on the financial development in model 5, 7 and 8. However, it has statistically significant but economically insignificant impact on the financial development in model 7. Thus, do not reject $\mathrm{H} 0$, when financial development is measured by making use of bank z-score, stock market turnover and stock market volatility in model 5,8 and 9 respectively.

Oil prices have also different impact on the financial development across various measures. It has statistically and economically significant positive as well as negative impact on the financial development. Thus, it can be inferred financial development is influenced with decrease and increase in oil prices as it is sensitive to various measures. Moreover, oil prices negatively moderates the relationship between energy consumption and oil prices.

Therefore, this research highlights the impact of energy consumption on financial development. Thus, it can be inferred that, it is most essential to focus on the measures that have been used for financial development. Hence, the results of this study shows variations in the results due to several measures. Moreover, oil prices negatively moderates the relationship between energy consumption and financial development of emerging economies.

\section{References}

Ahmed, M., Riaz, K., Khan, A. M., \& Bibi, S. (2015). Energy consumption-economic growth nexus for Pakistan: Taming the untamed. Renewable and Sustainable Energy Reviews, 52, 890-896. http://dx.doi.org/10.1016/j.rser.2015.07.063

Al-mulali, U., \& Sab, C. N. B. C. (2012). The impact of energy consumption and CO 2 emission on the economic and financial development in 19 selected countries. Renewable and Sustainable Energy Reviews, 16(7), 4365-4369. http://dx.doi.org/10.1016/j.rser.2012.05.017

Asafu-Adjaye, J. (2000). The relationship between energy consumption, energy prices and economic growth: Time series evidence from Asian developing countries. Energy Economics, 22(6), 615-625. http://dx.doi.org/10.1016/S0140-9883(00)00050-5

Çoban, S., \& Topcu, M. (2013). The nexus between financial development and energy consumption in the EU: A dynamic panel data analysis. Energy Economics, 39, 81-88. http://dx.doi.org/10.1016/j.eneco.2013.04.001

Hasnaoui, H. (2014). The Nexus between Financial Development and Energy Consumption in the High-Income OECD Members: A Dynamic Panel Data Analysis. Professionals Center for Business Research, 12.

Huang, B. N., Hwang, M. J., \& Yang, C. W. (2008). Causal relationship between energy consumption and GDP growth revisited: A dynamic panel data approach. Ecological Economics, 67(1), 41-54. http://dx.doi.org/10.1016/j.ecolecon.2007.11.006

Komal, R., \& Abbas, F. (2015). Linking financial development, economic growth and energy consumption in Pakistan. Renewable and Sustainable Energy Reviews, 44, 211-220. http://dx.doi.org/10.1016/j.rser.2014.12.015

Lee, C. C., \& Chang, C. P. (2005). Structural breaks, energy consumption, and economic growth revisited: Evidence from Taiwan. Energy Economics, 27(6), 857-872. http://dx.doi.org/10.1016/j.eneco.2005.08.003

Lee, C. C., \& Chang, C. P. (2007). Energy consumption and GDP revisited: A panel analysis of developed and developing countries. Energy Economics, 29(6), 1206-1223. http://dx.doi.org/10.1016/j.eneco.2007.01.001

Mehrara, M. (2007). Energy consumption and economic growth: The case of oil exporting countries. Energy Policy, 35(5), 2939-2945. http://dx.doi.org/10.1016/j.enpol.2006.10.018

Naser, H. (2015). Analysing the long-run relationship among oil market, nuclear energy consumption, and economic growth: An evidence from emerging economies. Energy, 89, 421-434. 
http://dx.doi.org/10.1016/j.energy.2015.05.115

Odhiambo, N. M. (2010). Energy consumption, prices and economic growth in three SSA countries: A comparative study. Energy Policy, 38(5), 2463-2469. http://dx.doi.org/10.1016/j.enpol.2009.12.040

Sadorsky, P. (2010). The impact of financial development on energy consumption in emerging economies. Energy Policy, 38(5), 2528-2535. http://dx.doi.org/10.1016/j.enpol.2009.12.048

Sadorsky, P. (2011). Financial development and energy consumption in Central and Eastern European frontier economies. Energy Policy, 39(2), 999-1006. http://dx.doi.org/10.1016/j.enpol.2010.11.034

Shahbaz, M., Hye, Q. M. A., Tiwari, A. K., \& Leitão, N. C. (2013). Economic growth, energy consumption, financial development, international trade and $\mathrm{CO}_{2}$ emissions in Indonesia. Renewable and Sustainable Energy Reviews, 25, 109-121. http://dx.doi.org/10.1016/j.rser.2013.04.009

$\mathrm{Wu}$, L., \& Broadstock, D. C. (2015). Does economic, financial and institutional development matter for renewable energy consumption? Evidence from emerging economies. International Journal of Economic Policy in Emerging Economies, 8(1), 20-39. http://dx.doi.org/10.1504/IJEPEE.2015.068246

\section{Copyrights}

Copyright for this article is retained by the author(s), with first publication rights granted to the journal.

This is an open-access article distributed under the terms and conditions of the Creative Commons Attribution license (http://creativecommons.org/licenses/by/4.0/). 